\title{
Discussion of Rautenstein's paper on the "Use of actinophages for the classification of Actinomycetales"
}

\section{Welsch}

Labor. Microbiol. Gen. et Med. Univ. Leige, 32 Boulegard de la Constitution, Liege, Belgium

After hearing Dr. Rautenstein's well documented and stimulating report, I wish first to stress some of the points about which I entirely agree with him.

Our own experience confirms Rautenstein's contention that the reactions toward a given actinophage of any given actinomycete, isolated and maintained in artificial culture, are quite stable. Unless specific selection procedures are voluntarily used, changes from resistance to sensitivity, and vice versa, are very rare indeed.

The widespread occurrence of actinophages in nature, either free in natural substrates or produced by lysogenic actinomycetes, is also shown by our work (1), and we are in complete agreement with the conclusion that, generally speaking, actinophages from lysogenic organisms have a more restricted spectrum of activity than actinophages found in the free state (2).

The proportion of actinomycetes found by us to be lysogenic is not as high as that reported by Rautenstein $(2,3)$. However, it should be underlined that the discovery of a lysogenic organism by standard screening tests is possible only on condition that one has a suitable sensitive indicator strain available. Therefore, the systematic use of a large number of indicators, or a mere matter of chance, may explain why one investigator detects more lysogens than another within a similar, or even identical, series of strains examined. In addition, one should be aware that cultures of actinomycetes are sometimes capable of carrying an associated actinophage $(3,4)$ without being truly lysogenic, in the sense that they propagate a prophage $(3,5)$.

We have not observed, as Rautenstein did, the mutation of temperate phages from lysogenic actinomycetes to a state of virulence giving them the ability to lyse the organisms carrying the original prophage. Neither did we detect a host-induced widening of the lytic spectrum. However, we observed spontaneous host-range mutations (6) and reported that phenotypic host-induced quantitative variations of spe- 
cific activity (i. e. variations in the number of plaques respectively obtained on different indicators according to which one of them was used to produce the lysate titrated) could be of help to evaluate the closeness of relationship between a number of unknown actinomycetes $(3,7)$.

I finally wholeheartedly agree with Rautenstein's statement that the number of specific actinophages at present available is unfortunately not great. I would even stress that, up till now, actinophages capable of lysing a large number of species have not been isolated at all, although extensive investigations, involving the use of several methods for specific enrichment, were undertaken (2).

In the course of our screening programme, a number of actinophages were isolated $(1,2)$. Four of them, on account of their unusual features, were retained for a detailed electron-microscopic study (8). These viruses were shown and briefly described at the meeting.

When we suggested that actinophages might prove useful to recognize and classify actinomycetes (9), our contention was that phage sensitivity could and should be regarded, in some instances at least, as one of the many characters which, together, define a group, a species or a type within the species. Our position has not changed. To rely solely, or even mainly, on phage sensitivity to identify a species would serve to confuse the concepts of species and phagotype. These may occasionally coincide, but they generally do not. In other bacterial groups, phage-typing has been mainly useful to individualize types within a well-defined species, much more rarely to circumscribe the limits of a species.

It should also be kept in mind that, in some well-known cases, important properties are genetically controlled not by the bacterial genome, but by a carried prophage. Loss of the latter could, therefore, modify the phage-typing pattern and some properties believed to be specific of the host in such a way that it might emerge as a different species, if one ignored the basic mechanism responsible for the changes observed.

Considering the highly complex and dynamic situation which prevails between specific phages and bacterial species such as Corynebacterium diphthe riae, Staphylococcus aureus, Salmonella spp., and others, following the pressure of ecological factors and selection, it appears very likely that similar factors play a similar role in the evolution of actinomycetes. 
To conclude, we believe that actinophage sensitivity can be used with advantage in many instances to ascertain the relationship between different isolates of actinomycetes, but that such a test has little significance if it is not corroborated by the observation of a number of other properties.

\section{REFERENCES}

1. Bacq, C. M. and L. Die rickx (1962) Purification de l'actinophage $\phi 17$. Biochim. Biophys. Acta 61(11):1928; Lhoest, J. (1957) Propriétés antigeniques de quelques actinophages. C. R. Soc. Biol. Paris 151:1042-1045; Welsch, M. (1956) Actinophages dans les milieux naturels. C. R. Soc. Biol. Paris 150:1496-1499; Welsch, $M$. and $A$. Minon (1955) Inactivation the rmique d'actinophages. ibid. 149:207-210; (1955) Inactivation d'actinophages par ir radiation ultraviolette. ibid. 149:1309-1312.

2. Welsch, M., A. Rutten-Pinckaers and M. Selman (1963) Recherches sur les streptomyces d'Afrique Centrale IV. Iso-antibiose, lysogénie et actinophages libres. Bull. Soc. Roy. Sci. Liège 32(7-8):529-574.

3. (1959) Lysogenicity in streptomycetes. Ann. N. Y. Acad. Sci. 81(4):974-993; (1958) Lysogenic streptomycetes. Bull. Res. Counc. Israel $7 \mathrm{E}(1 / 2): 141-154$.

4. (1994) Tentatives de lysogénisation de Streptomyces griseus. C. R. Soc. Biol. Paris 148:726-728; (1956) Production d'actinophages par le mycélium résiduel dévelopé après lyse bactériophagique d'un streptomyces. ibid. 150:812-814; (1957) The behaviour towards actinophages of mutants surviving its lytic action. Leeuwenhoek ned. Tijdschr. 23(1):59-80.

5. (1956) Evidence for the occurrence of true lysogeny among actinomycetes. Virology $2(5): 703-704$.

6. (1954) Mutation d'un actinophage. C. R. Soc. Biol. Paris 148:2099-2102; Mattern, Ina E. and C. M. Bacq (1963) Comparaison de deux actinophages: Le "hostrange" mutant $\phi 17 / 5$ et la souche mère $\phi 17$. Biochim. Biophys. Acta 78(1):221-223.

7. (1956) The specificity of actinophage $\phi 17$. Giorn. Microbiol. $1(5): 339-348$.

8. Bacq, C. M. and R.W. Horne (1963) Morphology of actinophage $\phi$ 17. J. Gen. Microbiol. 32(1):131-133; Coyette, $\mathrm{J}$. and C. M. Calberg-Bacq (in press). 
9. Welsch, M. (1956) Discussione generale. Primo Sympos. Europaeo Biochemica degli Antibiotici 1956. Giorn. Microbiol. 2:100; (1959) Remarks on classification of Streptomyces. Intl. Bull. Bact. Nomencl. Tax. 9(1): 27-29; (1959) Use of the bacteriophage phenomenon for identification and classification of Actinomycetes. Mikrobiologiya 28(3):451-459; Welsch, M. et A. Pinkaers (1957) Premier essai de classement des streptomycetes par lysotypie. C. R. Soc. Biol., Paris 151:1283-1285; Welsch, M. , R. Corbaz and L. Ettlinger (1957) Phage typing of Streptomycetes. Schweiz. A. Path. 20(4):454458. 